\title{
Cladocera species composition in lakes in the area of the Hornsund Fjord (Southern Spitsbergen) - preliminary results
}

\author{
E. Zawisza(1) ${ }^{(1)}$ K. Szeroczyńska ${ }^{(1)}$
}

Received December 5, 2010

Revised February 24, 2011

Accepted March 8, 2011

Key-words: Cladocera species composition, Spitsbergen, lakes, Hornsund Fjord

\section{ABSTRACT}

Species composition of benthic and planktonic Cladocera was analysed in four lakes and ponds located in the southern part of the Spitsbergen Island near the Fiord Hornsund. This is the first study to provide information on the species composition of the contemporary and subfossil Cladocera in this region. A total of eight Cladocera taxa were found in the sediments and waters of the lakes that have been chosen for the study. The sediments included remains of only five species, while seven Cladocera species were found in the zooplankton samples. The results imply that the lakes are subject to natural transformations driven by the fluctuating climate which was reflected by increasing the number of species, and in particular in the appearance of Bosmina longirostris. Absence of some littoral Cladocera species in the sediments (e.g., small Alona, Ophyroxus gracilis), with simultaneous occurrence of these species in the water, may be a result of physical and chemical processes influencing the destruction and lack of preservation of the remains in the sediments.

\section{RÉSUMÉ}

\section{Composition spécifique des cladocères des lacs d'une région du Fjord Hornsund (Sud-Spitzberg) - résultats préliminaires}

Mots-clés : composition spécifique des cladocères, lacs, Spitzberg, fjord de Hornsund
La composition spécifique des cladocères des sédiments et des eaux de quatre lacs et mares de la partie sud de l'île de Spitzberg, à proximité du fjord Hornsund, a été analysée. Cette étude représente la première approche de la composition spécifique de cladocères subfossiles du sud du Spitzberg. Un total de huit taxons a été trouvé dans les sédiments et les eaux des lacs étudiés. Les sédiments ne contiennent que les restes de cinq espèces, alors que sept espèces de cladocères sont trouvées dans les échantillons de zooplancton. Les résultats obtenus suggèrent que les lacs étudiés sont sujets à des changements naturels traduits par un accroissement du nombre d'espèces et en particulier dans l'apparition de Bosmina longirostris, espèce qui n'avait jamais été observée dans les sédiments de tels lacs. Pour cette raison, la présence de nouvelles espèces dans les eaux des lacs étudiés constitue probablement une conséquence aux meilleures conditions climatiques (principalement thermiques) aux hautes latitudes. L'absence de certaines espèces de cladocères dans les sédiments, et la présence simultanée de ces espèces dans l'eau, peuvent être le résultat de processus physiques ou chimiques conduisant à la destruction et à l'absence de préservation de restes dans les sédiments.

(1) Institute of Geological Sciences, Polish Academy of Sciences, Research Centre in Warsaw, Twarda 51/55, 00818 Warsaw, Poland, ezawisza@twarda.pan.pl 


\section{INTRODUCTION}

Lacustrine sedimentary deposits provide a unique opportunity to study the dynamic of environmental and climate changes (Korhola and Rautio, 2001; Smol, 2008; Bjerring et al., 2009). Lakes located at high latitudes are of particular interest to researchers. Arctic lakes are good sentinels of environmental changes caused by natural and anthropogenic factors because they respond very quickly to even slightest changes in the surrounding landscape and atmosphere (Douglas and Smol, 1999; Betts-Piper et al., 2004). Aquatic organisms represent an important element of research in lakes, particularly the zoo- and phytoplankton. Cladocera represent one of the main component of the lakes zooplankton and because their shells preserve well in sediments they are often used as proxies to reconstruct past environmental conditions in these ecosystems (Jeppesen et al., 2001; Kamenik et al., 2007; Smol, 2008; Galbarczyk-Gąsiorowska et al., 2009).

Most of the studies on contemporary and subfossil Cladocera in the high Arctic lakes have been conducted in Canada, Greenland, and Lapland (Brodersen and Anderson, 2000; Lauridsen et al., 2001; Rautio et al., 2003; Sarmaja-Korjonen et al., 2006; Szeroczyńska et al., 2007; Sweetman et al., 2008; Nevalainen, 2009), while only few studies have been done in the Svalbard Archipelago (Birks et al., 2004).

The main goal of our research was to describe species composition of modern and subfossil Cladocera in four lakes located in the southern part of Spitsbergen near the Fjord Hornsund. This information will be used in the future studies to determine the major factors that influence the trophic status of the lakes. The first results that have already been obtained suggest that the Cladocera species composition determined in the lakes studied differs significantly from those determined in other arctic regions. It probably results from various factors, such as: severe climatic conditions, the morphometry of the lakes, and the size and nature of catchments of the lakes. The results obtained also suggest significant changes occurring today (within the last few years) in the Cladocera species composition.

\section{DESCRIPTION OF THE STUDY SITE}

The current climate of Svalbard is arctic, with an average annual temperature of approximately $-6{ }^{\circ} \mathrm{C}$. The climate of the southwestern part of the Spitsbergen coast is somewhat more moderate than in the remaining part of the island. This area is under the influence of two water masses: the warmer West Spitsbergen Current and the colder Sorrkap Current (Swerpel, 1985). The average summer temperature for this area (June to August) is $4.6^{\circ} \mathrm{C}$, and the vegetation period last between 8 and 10 weeks. The coldest period is between January and April, with an average monthly temperature between -10 and $-14{ }^{\circ} \mathrm{C}$. The average precipitation for this region is $<400 \mathrm{~mm}$ per year, with maximum rainfall during summer periods (July) (Brázdil et al., 1988; Birks et al., 2004; Nowiński and Wiśniewska-Wojtasik, 2006).

Two biological activity periods can be distinguished in lakes located in the high Arctic the active and passive phase. The active phase is concurrent with the period of positive temperatures during the arctic summer when the hydrological network is functioning. The passive phase is related to the period of negative temperatures, and usually lasts from the middle of September to the end of May (Nowiński and Wiśniewska-Wojtasik, 2006; Wojtasik and Bryłka-Wołk, 2010). Generally, lakes on Spitsbergen are in the initial phase of limnological succession, characterised by very low production of organic matter (Nowiński and Wiśniewska-Wojtasik, 2006).

The four lakes (site 1 - lake constituting a drinking water reservoir for the Polish Polar Station, site 2 - lake located in the direct vicinity study site No. 1, site 3 - Lake Fugledammen, site 4 - Lake Revvatnet) that were subject of this study are located in the southern part of the Spitsbergen Island, west of the Polish Polar Station "Hornsund" in the vicinity of the Fjord Hornsund $\left(77^{\circ} 00^{\prime} \mathrm{N}\right.$; $15^{\circ} 33^{\prime} \mathrm{E}$; Figure 1$)$.

The lakes are situated on post-glacial marine terraces commonly occurring at the coast. (Rakusa-Suszczewski, 1963; Giżejewski, 1994; Nowiński, 2005). During the summer the 

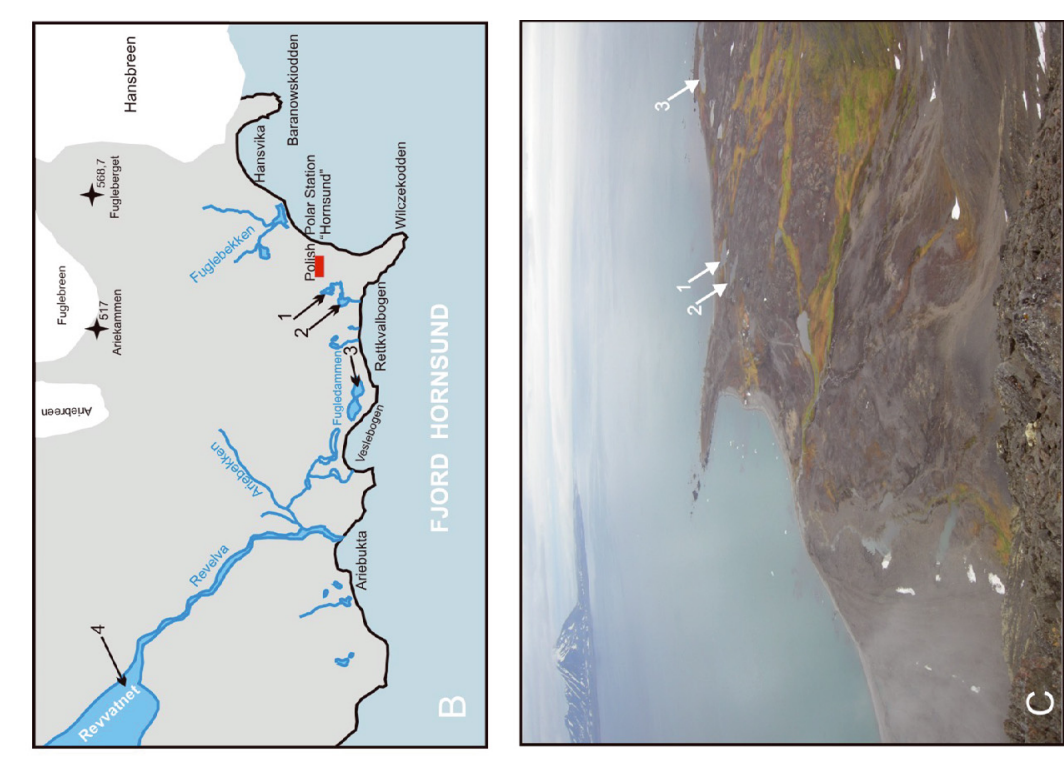

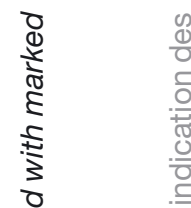

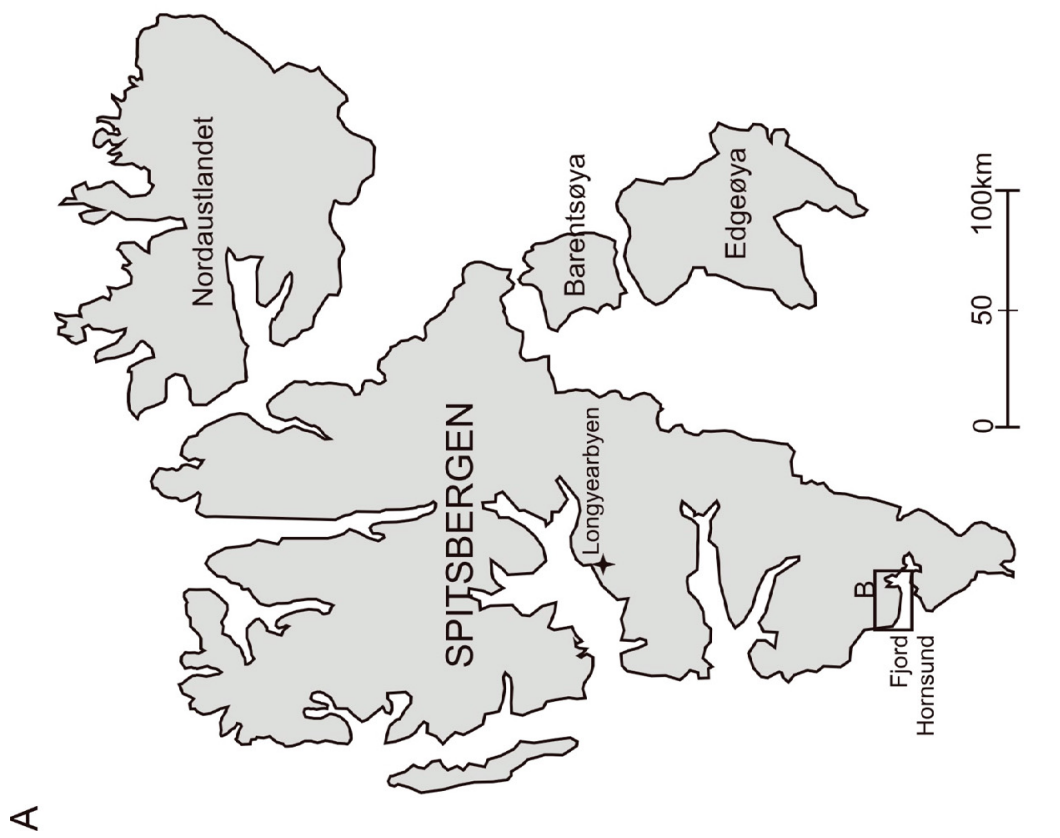

)

ำ

$\stackrel{5}{\frac{1}{2}}$

क्ष̃

$\frac{1}{2}$

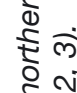

$\sin 2$

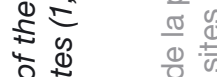

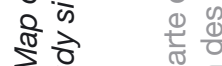

色兵

๖ं

है ส

호옹

ㅎํㅇํํ

잉하

ब

ᄂ 호

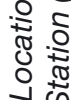

元

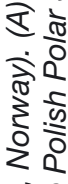

c)

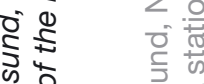

다 की

농 흥ㅎㅁ

요

눈ㅎㅀ

은.

का० कात

के $\frac{8}{9}$ वे

은

की

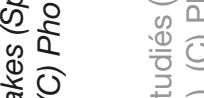

过

ते के के

के

o

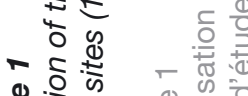

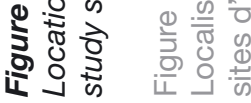




\section{Table I}

Lithology and core length of the four study sites.

Tableau I

Lithologie et longueur des carottes des quatre sites d'étude.

\begin{tabular}{|c|c|c|c|c|}
\hline Lake & $\begin{array}{c}\text { Surface } \\
\text { area }\end{array}$ & $\begin{array}{l}\text { Depth of } \\
\text { sampling site }\end{array}$ & $\begin{array}{l}\text { Core } \\
\text { length }\end{array}$ & Lithology \\
\hline \begin{tabular}{|l|} 
Study site No. 1 \\
water intake
\end{tabular} & 0.6 ha & $110 \mathrm{~cm}$ & $0-17 \mathrm{~cm}$ & Silts and medium sands \\
\hline Study site No. 2 & 0.7 ha & $80 \mathrm{~cm}$ & $0-8 \mathrm{~cm}$ & Silts and algal mats \\
\hline \begin{tabular}{|l|} 
Study site No. 3 \\
Fugledammen
\end{tabular} & $2.3 \mathrm{ha}$ & $90 \mathrm{~cm}$ & $0-18 \mathrm{~cm}$ & $\begin{array}{l}\text { Silts and fine sands with pebbles } \\
\text { of local rocks of up to } 1.0 \mathrm{~cm}\end{array}$ \\
\hline \begin{tabular}{|l|} 
Study site No. 4 \\
Revvatnet
\end{tabular} & 76 ha & \begin{tabular}{|c|}
$110 \mathrm{~cm}$ \\
$(\max$. depth $38 \mathrm{~m})$
\end{tabular} & $0-15 \mathrm{~cm}$ & \begin{tabular}{|c|} 
Silts and gravels and coarse sands \\
with pebbles of local rocks of up to $2.5 \mathrm{~cm}$
\end{tabular} \\
\hline
\end{tabular}

average conductivity of the lakes' water is $\sim 150 \mu \mathrm{S} \cdot \mathrm{cm}^{-1}$, and the oxygen content is $\sim 14.1 \mathrm{mg} \cdot \mathrm{dm}^{-3}$. The average water temperature in the studied lakes at the beginning of August 2007 amounted to approximately $8.4^{\circ} \mathrm{C}$, and pH varied between 7.4 and 7.7.

The lakes No. 1 and No. 2 are small, shallow and do not contain fish. They are classified as polymictic lakes. Continuous water mixing is observed during the summer and ceases completely during the winter, when the lakes freeze down to the bottom (Nowiński and Wiśniewska-Wojtasik, 2006).

Lakes Fugledammen (No. 3) and Revvatnet (No. 4) are larger, deeper, and are inhabited by fish. They are subject to significant mixing, but smaller than lakes No. 1 and No. 2 (Table I). All the lakes are extremely oligotrophic, although their fertility increases during the summer period due to expansion of bird colonies along the coast (Wojczulanis-Jakubas et al., 2008; Zmudczyńska et al., 2009).

\section{MATERIALS AND METHODS}

In order to determine species habitat affinities, Cladocera samples were collected from each lake's water column and sediment surface in July and August 2007. At the same time, a total of four sediment cores were retrieved from the same locations for analyses of past environmental conditions. The zooplankton samples were collected using a plankton net with a $40-\mu \mathrm{m}$ mesh, from the littoral zone of each lake, while the sediment cores were retrieved using a Kajak gravity corer and then sectioned into $1 \mathrm{~cm}$ slices. All samples were stored in plastic bags, transported to the laboratory on ice and preserved in alcohol until they could be processed. Lithologically, the sampled sediments were composed mainly of more or less organic fine-silts with sands and pebbles of local rocks (Table I).

The sediments of Lakes Fugledammen and Revvatnet were dated by means of the $\mathrm{Pb}-210$ method (Quaternary Geochronology Laboratory in the Institute of Geological Sciences, Polish Academy of Sciences in Warsaw, Poland), but the obtain results are not suitable for age model and the determination of the rate and time of sedimentation.

The sediment samples were prepared for subfossil Cladocera analysis according to the method described by Frey (1986). Coarse-grained sediments (including medium sands and gravels) were not stirred in a magnetic stirrer to prevent mechanical damage to Cladocera remains. Because of the poor preservation and/or low concentrations of cladoceran remains in the sediment samples, it was impossible to conduct any quantitative analyses using the obtained data. Therefore, all the results described in this manuscript are qualitative, in nature. The cladoceran remains (head shields, shells, postabdomens, postabdominal claws, and ephippia) were counted. The identification of species was carried out according to Flössner (1972, 2000) and Smirnov (1996) for freshwater samples, and Szeroczyńska and Sarmaja-Korjonen (2007) for Cladocera remains. 
Table II

Species composition of Cladocera from water and sediments in four study sites.

Tableau II

Composition spécifique des cladocères de l'eau et des sédiments des quatre sites d'études.

\begin{tabular}{|l|c|c|c|c|c|c|c|c|}
\hline \multirow{2}{*}{ Species } & \multicolumn{2}{|c|}{ Study site No. 1 } & \multicolumn{2}{l|}{ Study site No. 2 } & \multicolumn{2}{l|}{ Study site N0. 3 } & \multicolumn{2}{l|}{ Study site N0. 4} \\
\cline { 2 - 10 } & Water & Sediment & Water & Sediment & Water & Sediment & Water & Sediment \\
\hline Chydorus sphaericus & + & + & + & + & + & + & + & + \\
\hline Bosmina Iongirostris & + & & + & & + & & + & \\
\hline Daphnia pulex - group & & & + & + & + & + & & \\
\hline Small Alona (guttata) & + & & & & & & & \\
\hline Acroperus harpae & + & & & + & & + & & \\
\hline Eurycercus sp. & & & & & + & + & & \\
\hline Ophyroxus gracilis & & & & & + & & & \\
\hline Chydorus arcticus & & & & & & + & & \\
\hline
\end{tabular}

\section{RESULTS}

A total of five taxa were identified in the core samples. These were: Chydorus sphaericus (Müller, 1776), Daphnia-pulex group Leydig 1860, Acroperus harpae (Baird, 1835), Eurycercus sp. Baird, 1843, and Chydorus arcticus (?) (Røen, 1987) (Table II, Figure 2). Chydorus sphaericus (Figure 2D) was the only taxon that appeared in sediments of all the lakes. The remains of Daphnia pulex-group and Acroperus harpae (Figure 2C) were recorded only in the sediments of lakes Nos. 2 and 3, while Eurycercus sp. (Figure 2B) and Chydorus arcticus (?) (Figure 2A) in lake No. 3. In Lake Fugledammen (study site 3), remains of Cladocera belonging to genus Chydorus were found, classified by the authors as Chydorus arcticus (Figure 2A), a species described by Røen (1987). Because only the remains of shells and no head capsules were found, the determination of the species as Chydorus arcticus is uncertain.

Arctic Cladocera species are often classified as pioneer species because they can withstand even the most unfavourable environmental conditions (e.g., very low temperatures) and appear first in previously inhabited, often frozen aquatic ecosystems indicating the beginning of environmental change often cause by warming climate (Sarmaja-Korjonen et al., 2003; Bennike et al., 2004; Szeroczyńska, 2006).

Zooplankton samples collected from the water column included seven Cladocera species. Among these species, Chydorus sphaericus and Bosmina longirostris (Müller, 1785) occurred in all the studied lakes. The waters of lake No. 1 included species of Acroperus harpae and small Alona (guttata) Sars, 1862. Waters of lakes No. 2 and 3 contained species of the Daphnia pulex-group, which were also found in the lakes sediments (Table II).

\section{DISCUSSION}

The investigated lakes contained more Cladocera species in the water than in the sediment. The difference between species composition in the water column and sediment samples indicates recent changes in edaphic conditions and temperature. The only species occurring in both, sediment and water column was the cosmopolitan Chydorus sphaericus species. This species can tolerate broad changes in temperature and occurs in all types of lakes. Bosmina longirostris, which was exclusively recorded in the water column of all of the studied lakes, implies better edaphic condition. Occurrence of this species may indicate an increase of nutrients concentration in the water and probably an increase of water temperature (Locke and Sprules, 2000; Korhola and Rautio, 2001; Čeirāns, 2007; Sweetman et al., 2010). Additionally, Wiktor and Wojciechowska (2005) showed that improved thermal conditions in Spitsbergen during the last few years triggered development of macroalgae (mostly Chlorophyta) in the local lakes, which increased the supply of nutritious substances. Lack of Chydorus arcticus - a low temperature-tolerant species (Røen, 1987; Bennike, 2000; Sweetman et al., 2008), in 
E. Zawisza and K. Szeroczyńska: Knowl. Managt. Aquatic Ecosyst. (2011) 402, 04
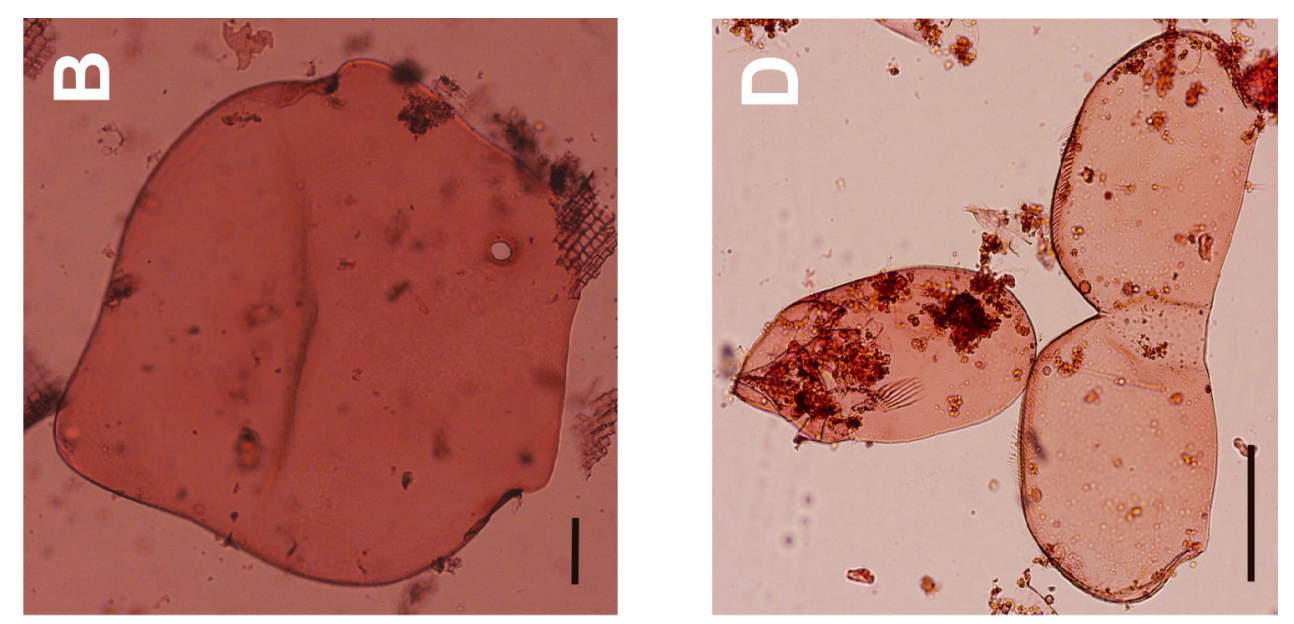

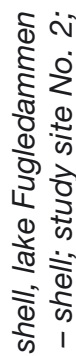

돈

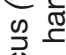

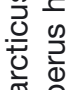

응 응

는 $\frac{0}{4}$

응ำ

বे

उิ

$\xi^{\infty}$

ㅇำ

ת 잉

$\frac{n}{\bar{m}}$

๑)

कิ

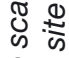

ॠ

के 究

위 है เ

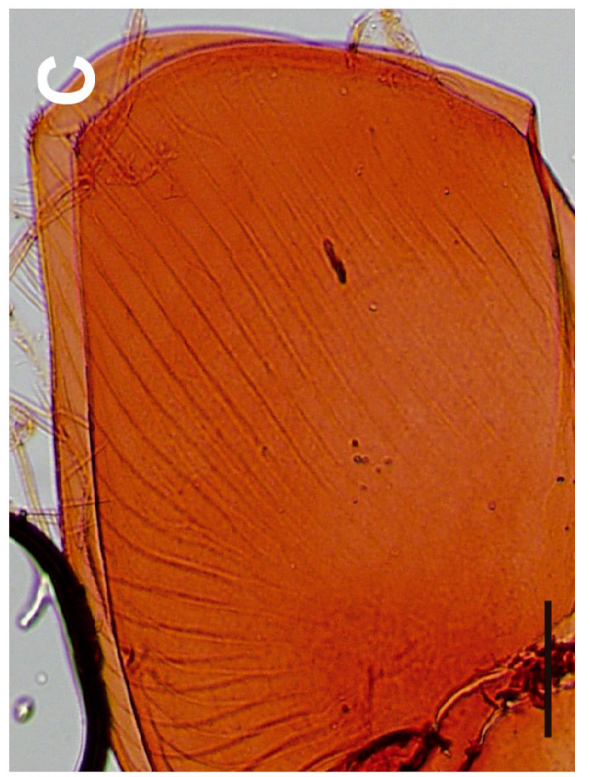

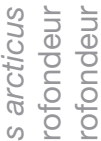
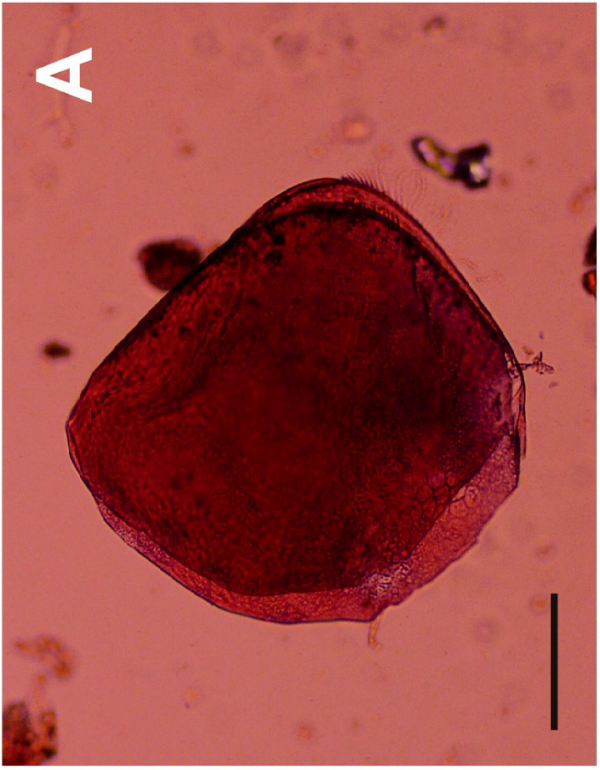

व ह

ई हิ बิ

क ठ ठ

흔

定。

(1)

०

(ฮ) จे

ส $\frac{0}{2}$ ำ

(1) क

क के

ऽ ฮิ

क ₹ क

है।

ఏ

के के

ญ

क $\frac{5}{5}$

\& क

ธ

؟ $\frac{1}{1}$

는

ㅇํㄴ은

ऽ ह ष्ठ

든 की

है। क

(1)

สํํㅇำ

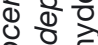

을

ণั

ত

○

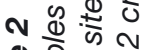

ड़ है के ई

운 离起 
the waters of the studied lakes may indicate increase of the average water temperature of the lakes due to the warming occurring in recent decades at higher latitudes.

Generally, the sediments of the Spitsbergen lakes included a small number of Cladocera species (Table II). The differences between the Cladocera occurring in the sediment and in the water are quite difficult to explain. Lack of certain species in the sediments, in spite of their occurrence in the water column, can be due to several reasons. One of which may be rapid destruction of the shells in the lake's bottom sediments. This process may be caused by a complete freezing of the lakes down to the bottom or physical damaging of the thin shells in sediments that are often composed of coarse-grained material. Another explanation of poor species preservation in sediments may be a large inter- and intra-annual temperature variability. We hypothesize that higher number Cladocera species in the water may be due to higher water temperature, which are probably a results of the climate warming observed in Arctic regions in recent years. A similar phenomenon was described by Sweetman et al. (2008) and Smol et al. (2005) in the case of lakes situated in the Arctic area of Canada. They found out that the migration of some species to high latitudes is related to the climate warming occurring in the Northern Hemisphere.

This pilot study suggests that more studies are necessary in the lakes on the Spitsbergen Island to improve our knowledge of Cladocera species distribution, composition and relationship to water quality. This knowledge is necessary before the studies of the past environmental conditions can begin.

\section{ACKNOWLEDGEMENTS}

We thank the reviewers for their reviewing and constructive criticism of the manuscript. This work was funded by the Ministry of Scientific Research and Higher Education, Grant "Polar Network" and by the Institute of Geological Sciences, Polish Academy of Sciences, Warsaw, Poland.

\section{REFERENCES}

Bennike O., 2000. Palaeoecological studies of Holocene lake sediments from west Greenland. Palaeogeogr. Palaeoclimatol. Palaeoecol., 155, 285-304.

Bennike O., Sarmaja-Korjonen K. and Seppänen A., 2004. Reinvestigation of the classic late-glacial Bølling Sø sequence, Denmark: chronology, macrofossils, Cladocera and chydorid ephippia. J. Quat. Sci., 19, 465-478.

Betts-Piper A.A., Zeeb B.A. and Smol J.P., 2004. Distribution and autecology of chrysophyte cysts from high Arctic Svalbard lakes: preliminary evidence of recent environmental change. J. Paleolimnol., 31, 467-481.

Birks H.J.B., Monteith D.T., Rose N.L., Jones V.J. and Peglar S.M., 2004. Recent environmental change and atmospheric contamination on Svalbard as recorded in lake sediments - modern limnology, vegetation, and pollen deposition. J. Paleolimnol., 31, 411-431.

Bjerring R., Becares E., DeClerck S., Gross E.M., Hansson L.-A., Kairesalo T., Nykänen M., Halkiewicz H., Kornijów R., Conde-Porcuna J.M., Seferlis M., Nõges T., Moss B., Amsinck S.L., Vad Odgaard B. and Feppesen E., 2009. Subfossil Cladocera in relation to contemporary environmental variables in 54 Pan-European lakes. Fresh. Biol., 54, 2401-2417.

Brázdil R., Chmal H., Kida J., Klementowski J., Konečny M., Pereyma J., Piasecki J., Prošek P., Sobik M. and Szczepankiewicz-Szmyrka A., 1988. Results of investigation of the geographical research expedition, Spitsbergen 1985, Univerzita J.E. Purkyně, Brno, 337 p.

Brodersen K.P. and Anderson N.J., 2000. Subfossil insect remains (Chironomidae) and lake-water temperature inference in the Sisimiut-Kangerlusuanq region, southern West Greenland. Geology of Greenland Survey Bulletin, 186, 78-82.

Čeirāns A., 2007. Zooplankton indicators of trophy in Latvian lakes. Acta Universitatis Latviensis, Biology, 723, 61-69. 
Douglas M.S.V. and Smol J.P., 1999. Freshwater diatoms as indicators of environmental change in the High Arctic. In: Stoermer E.F. and Smol J.P. (eds.), The Diatoms: Applications for the Environmental and Earth Sciences, Cambridge University Press, Cambridge, 227-244.

Flössner D., 1972. Branchiopoda, Branchiura. Die Tierwelt Deutschlands, 60, 1-501.

Flössner D., 2000. Die Haplopoda und Cladocera (ohne Bosminidae) Mitteleuropas, Backhuys Publisher, Leiden.

Frey D.G., 1986. Cladocera analysis. In: Berglund B.E. (ed.), Handbook of Holocene Palaeoecology and Palaeohydrology, Wiley, Chichester.

Galbarczyk-Gąsiorowska L., Gąsiorowski M. and Szeroczyńska K., 2009. Reconstruction of human influence on two small oxbow lakes. Hydrobiologia, 631, 173-183.

Giżejewski J., 1994. Preliminary report on sedimentary processes. In: Rev. Lake, XXI Symposium Polarne, Warszawa, 107-116.

Jeppesen E., Leavitt P., De Meester L. and Jensen J.P., 2001. Functional ecology and palaeolimnology: using cladoceran remains to reconstruct anthropogenic impact. Trends Ecol. Evol., 16, 191-198.

Kamenik Ch., Szeroczyńska K. and Schmidt R., 2007. Relationships among recent Alpine Cladocera remains and their environment - implications for climate-change studies. Hydrobiologia, 594, 33-46.

Korhola A. and Rautio M., 2001. Cladocera and other branchiopod crustaceans. In: Smol J.P., Birks H.J.B. and Last W.M. (eds.), Tracking Environmental Change Using Lake Sediments, Zoological Indicators, Vol. 4, Kluwer Academic Publishers.

Lauridsen T., Jeppesen E., Landkildehus F. and Søndergaard M., 2001. Horizontal distribution of cladocerans in arctic Greenland lakes - impact of macrophytes and fish. Hydrobiologia, 442, 107-116.

Locke W.A. and Sprules G., 2000. Effects of acidic pH and phytoplankton on survival and condition of Bosmina longirostris and Daphnia pulex. Hydrobiologia, 437, 187-196.

Nevalainen L., 2009. Autumnal chydorid fauna (Anomopoda, Chydoridae) in Kevo region, northern Finnish Lapland. Kevo notes, 13, 1-20.

Nowiński K., 2005, Abiotyczne właściwości wody wybranych zbiorników rejonu Hornsundu (Płd.-Zach. Spitsbergen). Czasopismo Geograficzne, 76, 105-119.

Nowiński K. and Wiśniewska-Wojtasik B., 2006. Diversity of abiotic properties of water in shallow lakes in Hornsund area (SW Spitsbergen). Limnological Review, 6, 215-22.

Rakusa-Suszczewski S., 1963. Thermics and chemistry of shallow fresh water pools in Spitsbergen. Pol. Arch. Hydrobiol. XI (XXIV), 2, 169-187.

Rautio M., Korhola A. and Zellmer I.D., 2003. Vertical distribution of Daphnia longispina in shallow subarctic pond: Does the interaction of ultraviolet radiation and Chauborus predation explain the pattern? Polar Biology, 26, 659-665.

Røen U., 1987. Chydorus arcticus n.sp., a new cladoceran crustacean (Chydoridae: Chydorinae) from the North Atlantic Arctic and Subarctic areas. Hydrobiologia, 14, 125-130.

Sarmaja-Korjonen K., Szeroczyńska K. and Gąsiorowski M., 2003. Subfossil Chydorid taxa and assemblages from Lake sediments in Poland and Finland with special reference to climate. Studia Quaternaria, 20, 25-34.

Sarmaja-Korjonen K., Nyman M., Kultti S. and Valiränta M., 2006. Palaeolimnological development of Lake Njargajarvi, northern Finnish Lapland, in a changing Holocene climate and environment. J. Paleolimnol., 35, 65-81.

Smirnov N.N., 1996. Cladocera: The Chydorinae and Sayciinae (Chydoridae) of the World, SPB Academic Publishing, Amsterdam, 197 p.

Smol J.P., 2008. Pollution of Lakes and Rivers: A Paleoenvironmental Perspective, 2nd edition, Wiley-Blackwell, $396 \mathrm{p}$.

Smol J.P., Wolfe A.P., Birks H.J., Douglas M.S., Jones V.J., Korhola A., Pienitz R., Rühland K., Sorvari S., Antoniades D., Brooks S.J., Fallu M.A., Hughes M., Keatley B.E., Laing T.E., Michelutti N., Nazarova L., Nyman M., Paterson A.M., Perren B., Quinlan R., Rautio M., Saulnier-Talbot E., Siitonen S., Solovieva N. and Weckstrom J., 2005. Climate-driven regime shifts in the biological communities of Arctic lakes. Proc. Nat. Acad. Sci. USA, 102, 4397-4402.

Sweetman J.N., La Face E., Rühland K.M. and Smol J.P., 2008. Evaluating the response of Cladocera to recent environmental changes in lakes from the central Canadian Arctic treeline region. Arctic, Antarctic, and Alpine Res., 40, 584-591. 
Sweetman J.N., Rühland K.M. and Smol J.P., 2010., Environmental and spatial factors influencing the distribution of cladocerans in the lake across the central Canadian Arctic treeline region. J. Limnol., $69,76-87$.

Swerpel S., 1985. The Hornsund Fjord: Water Masses. PPRes., 6, 475-496.

Szeroczyńska K., 2006. The significance of subfossil Cladocera in stratigraphy of Late Glacial and Holocene. Studia Quaternaria, 23, 37-45.

Szeroczyńska K. and Sarmaja-Korjonen K., 2007. Atlas of Subfossil Cladocera from Central and Northern Europe, Friends of the Lower Vistula Society, 84 p.

Szeroczyńska K., Tatur A., Weckström J., Gąsiorowski M., Noryśkiewicz A.M. and Sienkiewicz E., 2007. Holocene environmental history in northwest Finnish Lapland reflected in the multi-proxy record of small subarctic lake. J. Paleolimnol., 38, 25-47.

Wiktor J. and Wojciechowska K., 2005. Differences in taxonomic composition of summer phytoplankton in two fjords of West Spitsbergen. Svalbard. PPRes., 26, 259-268.

Wojczulanis-Jakubas K., Jakubas D. and Stempniewicz L., 2008. Awifauna of Hornsund area, SW Spitsbergen: present state and recent changes. PPRes., 29, 187-197.

Wojtasik B. and Bryłka-Wołk M., 2010. Reproduction and genetic structure of a freshwater crustacean Lepidurus arcticus from Spitsbergen. PPRes., 31, 33-44.

Zmudczyńska K., Zwolicki A., Barcikowski M.,Barcikowski A. and Stempniewicz L., 2009. Spectral characteristics of the Arctic ornithogenic tundra vegetation in Hornsund area, SW Spitsbergen. PPRes., 30, 249-262. 